ideas. Vern Suomi, a pioneer in remote sensing of our planet, described his views of how technology can be developed and utilized. The fascinating new age of computing capabilities was graphically described by Larry Smarr. Director of the National Center for Computer Applications. Perspectives on operational oceanography and academic oceanography were given by Rear Admiral Dick Pittenger. An entertaining look at global environmental change from the viewpoint of the geochemist was given by Karl Turekian. Finally, Roger Revelle took us through technological advances and their impacts on the marine sciences. We mourn the recent loss of Roger, whose many accomplishments and honors are highlighted elsewhere in this issue.

There was an excellent representation of college students, both in terms of poster pre- sentations and participation in dialogue. A special session, "Careers in Oceanography," was conceived by local organizing committee chairman Peter Betzer. High school students and teachers participated in this session. The program included presentations concerning various aspects of careers in oceanography from the perspectives of scientists in various disciplines (Alice Alldredge, biological; Tom Dickey, physical; Bob Duce, atmospheric and oceanic chemistry; Bill Landing, chemical; and Margaret Leinen, geological). The panel answered questions that followed their presentations.

The final registration for the meeting totaled 527 (with 139 abstracts); 109 students attended. In addition, an open business meeting of TOS was held and plans for the next meeting were addressed.
From my own perspective, I accepted the challenge as program chairman in part because of the great success of the inaugural meeting under the leadership of Rana Fine and the organizational groundwork put in place by the TOS staff. In addition, I view the chairmanship as both an honor and an opportunity to interact with many of the world's leading oceanographers. Finally, I thank TOS staff, especially Judi Powell and Jim Baker; the meetings and program committee, chaired by Stan Wilson; the local organizing committee, chaired by Peter Betzer; the session chairs, speakers, and poster presenters; and the staff of E.H. Pechan, especially Annette Najjar. Their efforts made the second TOS meeting a successful and enjoyable event. $\square$

\title{
SUMMARY OF THE OCEANOGRAPHIC SOCIETy ST. Petersburg MEeting QUESTIONNAIRE
}

\author{
By Judi Powell
}

\begin{abstract}
IN ORDER TO GET REACTIONS from those who attended, a questionnaire was distributed at the Society's second scientific meeting in St. Petersburg. The information will be used in planning future meetingscontinuing and improving upon the favorable aspects and correcting the negative elements. The following is a brief summary of the highlights.
\end{abstract}

\section{The Positives}

The majority of respondents offered favorable remarks. The format of the meetinga single daily plenary followed by a poster session, all focused on a daily theme-received high marks. Adequate time for social/ scientific interaction was highly praised. Many feel this unique combination is the secret to the success of TOS meetings and urged us to maintain the format. The registration fee was seen as "reasonable" to "a bargain," considering that it included meals, functions, and a quality meeting. The hotel and theater facilities as well as the social functions were highly rated.

\section{The Negatives}

The majority of negative remarks concerned the audiovisual presentations. TOS needs to improve the level of audiovisual support for the speakers and to encourage speakers to improve the caliber of their visual aids. Some attendees also thought we needed to stress the importance of overview presen- tations by the invited speakers in order to achieve our goal of an interdisciplinary forum.

\section{Things to Think About and/or Work On}

- Include more women in the program.

- Give TOS awards.

- Encourage international and minority participation.

- Allow more publicity and promotional lead time.

- Provide a written record of the meeting.

- Close meeting with plenary session on "hot topics."

- Provide a booth for listing employment opportunities and resume drop-off.

We thank each of you who took the time to give us your comments. Every comment has been noted and we will review the complete list when planning the next meeting. $\square$ 